\title{
ANALISIS HASIL HITUNG JENIS LEUKOSIT PADA BAYI YANG DIBERI ASI EKSKLUSIF DENGAN YANG DIBERI SUSU FORMULA
}

\section{ANALYSIS OF RESULTS CALCULATE LEUKOCITES IN BABY BE GIVEN WITH EXCLUSIVE BREAST MILK FORMULA}

\author{
Mursalim ${ }^{1}$, Syahida Djasang ${ }^{2}$ \\ Jurusan Analis Kesehatan \\ *liemachmad@gmail.com
}

\begin{abstract}
ABSTRAK
Penelitian ini dilakukan untuk mengetahui perbandingan serta gambaran hasil pemeriksaan hitung jenis leukosit pada bayi yang diberi ASI eksklusif dengan yang diberi susu formula. ASI merupakan nutrisi bagi bayi yang diperlukan selama masa pertumbuhan dan perkembangan bayi serta meningkatkan daya tahan dan mengandung anti bakteri serta anti virus yang melindungi bayi terhadap infeksi. Imunitas tubuh dapat diketahui melalui ketahanan tubuh innate (non spesifik) yang diwakili oleh eosinofil, basofil, neutrofil dan monosit, sedangkan ketahanan tubuh adaptif (spesifik) diwakili immunoglobulin yaitu lgG, IgM, dan limfosit. Penelitian ini bertujuan untuk mengetahui gambaran hasil hitung jenis leukosit pada bayi yang diberi ASI dan susu formula. Penelitian ini dilaksankan di Laboratorium Patologi Analis Kesehatan Poltekkes Makassar pada bulan Mei sampai dengan September 2018. Jenis penelitian ini adalah penelitian descriptive. Hasil penelitian menujukkan Tidak ada perbedaan bermakna pada kesan jenis lekosit pada bayi yang mengkonsumsi asi dan susu formula kecuali pada Monosit ada perbedaan secara bermakna.Adapun saran untuk penelitian selanjutnya agar parameter pemeriksaan laboratorium di perluas atau di perbanyak.
\end{abstract}

Kata Kunci : Bayi, Hitung Jenis Leukosit, ASI, Susu Formula

\section{ABSTRACT}

This study was conducted to determine the comparison and description of the results of leukocyte count tests in infants fed exclusively breastfed with formula-fed milk. Breast milk is a nutrient for babies that is needed during the growth and development of infants and increases endurance and contains anti-bacterial and anti-viral properties that protect babies against infection. Body immunity can be known through thebody resistance innate (non-specific)represented by eosinophils, basophils, neutrophils and monocytes, whilebody resistance adaptiveis (specific)represented by immunoglobulin namely $\lg G$, IgM, and lymphocytes. This study aims to describe the results of leukocyte counts in breastfed infants and formula milk. This research was conducted at the Makassar Polytechnic Health Pathology Laboratory in May to September 2018, with a total sample of 77 babies consisting of 33 samples from breast-fed infants and 44 samples from infants who consumed formula milk. This type of research is descriptive. The results showed no significant differences in the impression of leukocytes in infants who consumed breast milk and formula milk except in Monocytes there were significant differences. As for suggestions for further research so that the laboratory inspection parameters are added with a larger number of samples.

Keywords: infants, leukocyte count, breast milk (ASI), formula milk

\section{PENDAHULUAN}

Kesehatan anak merupakan salah satu masalah utama dalam bidang kesehatan yang terjadi saat ini di Indonesia. Kekebalan tubuh anak umur dibawah sepuluh tahun masih rendah, serta organ tubuh seperti otak, saluran pernafasan dan saluran pencernaan yang masih belum begitu sempurna sehingga sangat rentan terhadap virus dan bakteri serta terjadinya perubahan suhu. Banyak penyakit berbahaya yang dapat membahayakan nyawa serta kesehatan fisik maupun mental anak pasca sakit.

Dalam kehidupan modern saat ini, jumlah wanita yang aktif bekerja semakin tinggi. Data empiris menunjukkan bahwa peningkatan ini umumnya didominasi oleh dua hal yaitu kebutuhan ekonomi dan juga alasan pengembangan karir wanita.Tuntutan untuk meluangkan waktu yang lebih untuk keperluan kerja di luar rumah membuat waktu untuk menyusui anak semakin berkurang. Dalam kondisi seperti ini tampaknya susu formula merupakan alternatif pemecahan masalah untuk menggantikan sebagian ASI bagi bayi. Disamping kedua alasan ini, secara alamiah terdapat variasi produksi ASI pada wanita dalam periode menyusui. Ada wanita yang memproduksi ASI cukup dan bahkan berlebihan untuk bayinya, akan tetapi di lain pihak ada ibu menyusui yang tidak cukup memperoduksi ASI untuk bayinya (Noor Ronny 2017).

Berdasarkan data tahun $2004-2008$ cakupan pemberian ASI ekslusif di Indonesia berfluktuasi dan cenderung mengalami penurunan. Cakupan pemberian ASI ekslusif pada bayi $0-6$ bulan turun dari $62,2 \%$ pada 
tahun 2007 menjadi $56,2 \%$ pada tahun 2008, sedangkan pada bayi sampai 6 bulan turun dari $28,6 \%$ pada tahun 2007 menjadi $24,3 \%$ pada tahun 2008 (Marnoto, 2013).

Keunggulan ASI sebagai nutrisi bayi telah banyak dipelajari dan dibuktikan oleh para peneliti sehingga Organisasi Kesehatan Dunia (WHO) merekomendasikan ASI eksklusif untuk bayi sampai berumur 6 bulan dan kemudian dilanjutkan bersama makanan pendamping ASI sampai bayi berumur 2 tahun atau lebih. Meskipun demikian angka menyusui eksklusif di Indonesia menurut Survey Demografi dan Kesehatan Indonesia (SDKI) tahun 2007 baru mencapai 32\% dan bayi yang dilahirkan di fasilitas kesehatan cenderung diberi susu formula (Marnoto, 2013).

ASI sangat diperlukan selama masa pertumbuhan dan perkembangan bayi karena selain mengandung zat nutrisi yang dibutuhkan, ASI juga meningkatkan daya tahan dan mengandung anti bakteri dan anti virus yang melindungi bayi terhadap infeksi. Dalam laporan WHO disebutkan bahwa hampir 90\% kematian balita terjadi di negara berkembang dan lebih dari $40 \%$ kematian disebabkan diare dan infeksi saluran pernafasan akut, yang dapat dicegah dengan pemberian ASI. Imunitas tubuh dapat diketahui melalui ketahanan tubuh innate (nonspesifik) diwakili oleh eosinofil, basophil, neutrofil, dan monosit, sedangkan ketahanan tubuh adatif (spesifik) diwakili oleh imunoglobulin, yaitu $\lg A$, IgG, IgM, dan Limfosit.

Proses Pembentukan Leukosit

Leukosit berasal dari dua garis keturunan sel punca hematopoetik multipolen yang sama, progenitor limfosit akan menghasilkan limfosit melalui jalur limfopoiesis sedangkan progenitor meiloid akan menghasilkan neutrofil, eosinofil dan basofil melalui jalur granulopoiesis dan monosit melalui jalur monositopoiesis.

1. Granulopoiesis

Proses pembentukan sel-sel seri granulosit berawal dari sel proginitor bersama yaitu mieloblas yang selanjutnya berkembang menjadi promielosit dan kemudian menjadi mielosit yang mulai menampakan adanya perbedaan jenis leukosit secara morfologis. Sel muda tersebt membentuk suatu kumpulan sel poliferatif atau mitotik yang selanjutnya akan menjadi metamieloit kemudian menjadi batang (stab) dan matang sebagai sel dengan inti bersegmen yang membentuk kompartemen pematangan pasca miosis.
Dalam keadaan normal, sumsum tulang mengandung banyak sel mieloid dibanding sel eritroid dengan perbandingan 2:1 sampai 12:1 dengan jumlah terbanyak neutrofil dan metamielosit. Setelah pelepasan dari sumsum tulang, masa hidup granulosit dalam sirkulasi 6-10 jam. Terdapat dua kumpulan granulosit yang sama besar dalam aliran darah, yaitu kumpulan yang bersirkulasi (circulating pool) yang biasanya termasuk ke dalam hitung sel darah dan kumpulan yang menepi (marginating pool) yang tidak termasuk ke dalam hitung sel darah. Dalam jaringan sel ini menghabiskan waktu sekitar 4-5 hari.

2. Monositopoiesis

Sel perkursor monosit sama dengan granulosit, yaitu mieloblas yang dapat berkembang menjadi monoblas yang merupakan sel muda yang sudah dapat dikenali sebagai sel yang akan menjadi monosit. Perkembangan selanjutnya akan membentuk promonosit dan matang menjadi monosit.

\section{Limfopoiesis}

Berbeda dengan granulosit dan monosit, sel proginitor limfosit berasal dari limfoid. Sel progenitor limfoid akan berkembang menjadi limfoblas yang kemudian akan menjadi prolimfosit dan terakhir akan menjadi limfosit.

Beberapa sel limfosit akan bermigrasi menuju timus dan akan mengalami deferensiasi menjadi sel $\mathrm{T}$ matang selama perjalanan dari korteks menuju medula. Sedangkan limfosit yang tetap menetap dalam sumsum tulang akan matang sebagai sel limfosit $\mathrm{B}$, jika terjadi pengenalan antigen selama sel limfosit $B$ bersirkulasi dalam darah tepi, sel limfosit B akan mengalami pematangan menjadi sel $\mathrm{B}$ memori atau sel plasma.

Tujuan penelitian ini adalah Untuk mengetahui gambaran hasil laboratorium hitung jenis leukosit pada bayi yang diberi ASI eksklusif dengan yang diberi susu formula

\section{Metode Penelitian}

Penelitian ini merupakan jenis penelitian deskriptif dengan rancangan cross sectional (belah lintang) untuk menggambarkan hasil pemeriksaan hitung jenis leukosit terhadap bayi yang diberi ASI eksklusif dengan yang diberi susu formula. 


\section{Populasi dan Sampel}

1. Populasi Penelitian

Populasi pada penelitian ini adalah bayi yang ada di beberapa Puskesmas dan Rumah Sakit yang ada di Kotamadya Makassar.

2. Teknik Pengambilan Sampel

Pengambilan sampel yang dilakukan dengan teknik purposive sampling yaitu pengambilan sampel yang cukup dengan kriteria yang telah ditetapkan dan waktu selama dalam penelitian.

\section{Instrumen Penelitian}

Intrumen yang digunakan dalam penelitian ini adalah lembar quisioner dan PSP (Penjelasan sebelum persetujuan) kapas alkohol $70 \%$, kaca objek, autoclick..

\section{Bahan Penelitian}

Bahan penelitian yang digunakan dalam penelitian ini adalah whole blood, EDTA, oil imersi, metanol, Aquadest dan Giemsa.

\section{Prosedur Penelitian}

Pra Analitik

1. Disiapkan peralatan dan bahan pemeriksaan

2. Dilakukan pengambilan darah kapiler

3. Dibuat preparat sediaan apus darah tipis

Analitik

Teknik Pewarnaan

1. Diletakkan preparat sediaan apus darah tipis di atas rak pewarna, bagian apusan menghadap ke atas.

2. Diteteskan metanol ke atas preparat hingga menggenangi seluruh apusan darah, dibiarkan menggenangi selama 5 menit. Jika ada kelebihan metanol, dibuang dan dibiarkan sampai sediaan mengering di udara

3. Diteteskan larutan Giemsa di atas preparat hingga menggenangi apusan darah, dibiarkan selama 30 menit

4. Dibilas dengan aquadest, dikeringkan preparat di udara

Menghitung Jenis Leukosit

a. Diamati preparat di bawah mikroskop dengan pembesaran 1000 kali menggunakan oil imersi.

b. Ditentukan daerah perhitungan pada bagian eritrosit yang tersebar merata, dihitung jenis leukosit pada tiap lapang pandang secara zig zag.

1. Pasca Analitik

Pelaporan dan pencatatan hasil

Hasil.

Pada penelitian yang telah dilaksanakan pada Mei sampai September 2018 di Laboratorium Patologi Klinik Analis Kesehatan terhadap 77 sampel (33 sampel untuk bayi ASI dan 44 sampel bayi yang minum susu formula adalah sebagai berikut:

Tabel 1. Presentase Hasil Pemeriksaan Hitung Jenis Leukosit pada 33 Sampel Darah pada Bayi ASI

\begin{tabular}{|c|c|c|c|c|c|c|c|}
\hline & \multirow{2}{*}{$\begin{array}{c}\text { Jenis } \\
\text { Leuko } \\
\text { sit }\end{array}$} & \multicolumn{2}{|c|}{$\begin{array}{c}\text { Mening } \\
\text { kat }\end{array}$} & \multicolumn{2}{|c|}{$\begin{array}{c}\text { Normal } \\
\text { (\%) }\end{array}$} & \multicolumn{2}{|c|}{$\begin{array}{c}\text { Renda } \\
\text { h }\end{array}$} \\
\cline { 3 - 9 } & & Jl & $\%$ & Jml & $\%$ & JI & $\%$ \\
\hline 1 & Basofil & 0 & - & 33 & 100 & 0 & - \\
2. & $\begin{array}{c}\text { Eosino } \\
\text { fil }\end{array}$ & 0 & - & 33 & 100 & 0 & - \\
3. & $\begin{array}{c}\text { Neutro } \\
\text { fil }\end{array}$ & 0 & - & 33 & 100 & 0 & - \\
& & & & & &
\end{tabular}

$\begin{array}{llllllll}\text { 4. } & \begin{array}{c}\text { Monos } \\ \text { it }\end{array} & 0 & - & 33 & 100 & 0 & - \\ \text { 5. } & \begin{array}{l}\text { Limfosi } \\ \mathrm{t}\end{array} & 0 & - & 33 & 100 & 0 & -\end{array}$

Tabel 2. Presentase Hasil Pemeriksaan Hitung Jenis Leukosit pada 44 Sampel Darah pada Bayi Susu Formula

\begin{tabular}{|c|c|c|c|c|c|c|c|}
\hline \multirow[t]{2}{*}{ No } & \multirow{2}{*}{$\begin{array}{c}\text { Jenis } \\
\text { Leukosi } \\
\mathbf{t}\end{array}$} & \multicolumn{2}{|c|}{$\begin{array}{c}\text { Menin } \\
\text { g } \\
\text { kat }\end{array}$} & \multicolumn{2}{|c|}{ Normal } & \multicolumn{2}{|c|}{ Rendah } \\
\hline & & ال ال & $\%$ & ال & $\%$ & J & $\%$ \\
\hline 1 & Basofil & 0 & - & $\begin{array}{l}3 \\
3\end{array}$ & 100 & 0 & - \\
\hline 2. & Eosinofil & 0 & - & $\begin{array}{l}3 \\
3\end{array}$ & 100 & 0 & - \\
\hline 3. & Neutrofil & 1 & $\begin{array}{r}2,2 \\
7\end{array}$ & $\begin{array}{l}3 \\
2\end{array}$ & $\begin{array}{c}97,7 \\
3\end{array}$ & 0 & - \\
\hline
\end{tabular}

4. Monosit $0 \quad-\quad 3 \quad 100 \quad 0$

5. Limfosit $0 \quad-\begin{array}{llll}3 & 100 & 0 & -\end{array}$

Berdasarkan pada tabel 1 dan 2 menunjukkan bahwa jenis lekosit basophil eosinophil, monosit dan limposit tidak ada 
perbedaan akan tetapi pada jenis lekosit netrofil ada perbedaan dimana pada bayi non asi ada peningkatan $2,27 \%$.

Pada tabel 1 tersebut bahwa kesan lekosit pada sediaan darah tepi bayi dengan asi adalah semua normal, sedangkan pada bayi yang minum susu formula ada satu orang $(2,27 \%)$ yang mengalami peningkatan kadar netrofil.

\section{PEMBAHASAN}

Berdasarkan hasil uji statistik pada menunjukkan bahwa jenis lekosit yaitu Basofil. Eosinofil, Netrofil, dan limposit yang pada bayi yang mengkonsumsi Asi dengan yang diberi susu formula tidak ada perbedaan secara bermakana. Sedangkan pada jenis monosit terdapat perbedaan bermakna.

Dari hasil penelitian tersebut belum bisa menggambarkan bahwa kesan jenis lekosit pada bayi yang mengkonsumsi ASI lebih baik dari kesan lekosit yang mengkonsumsi susu formula.

Leukosit adalah sel darah putih yang diproduksi oleh jaringan hemopoetik yang berfungsi untuk membantu tubuh melawan berbagai penyakit infeksi sebagai bagian dari sistem kekebalan tubuh. Limfosit merupakan sekitar $30 \%$ dari leukosit saat lahir dan meningkat menjadi $60 \%$ pada 4 sampai 6 bulan. Mereka menurun menjadi $50 \%$ oleh 4 tahun, menjadi $40 \%$ oleh 6 tahun dan menjadi $30 \%$ oleh 8 tahun.

Jumlah monosit rata-rata neonatus lebih tinggi daripada nilai dewasa. Saat lahir proporsi ratarata monosit adalah $6 \%$. Selama masa bayi dan masa kanak-kanak, rata-rata 5\%. Bayi menunjukkan jumlah neutrofil absolut yang lebih besar daripada yang ditemukan pada anak yang lebih tua, yang secara khas mempertahankan dominasi limfosit.

Wanita yang baru lahir memiliki jumlah neutrofil rata-rata 2000 cells / mcL lebih tinggi daripada lakilaki; neonatus yang ibunya mengalami persalinan memiliki jumlah yang lebih tinggi daripada neonatus yang dilahirkan melalui seksio sesaria tanpa persalinan ibu sebelumnya. Ada beberapa bukti bahwa jumlah neutrofil absolut lebih rendah pada anak-anak kulit hitam yang sehat daripada pada anak kulit putih. Persentase eosinofil dan basofil tetap konsisten sepanjang masa bayi dan masa kanak-kanak.

Sistem kekebalan tubuh bayi belum sepenuhnya berkembang sampai berusia enam bulan. Sementara itu, antibodi imunoglobulin ibu hamil dapat melewati melalui melalui aliran darah plasenta, dan janin. Antibodi ini adalah bagian penting dari sistem kekebalan janin. Mereka mengidentifikasi dan mengikat zat berbahaya, seperti bakteri, virus, dan jamur yang masuk ke dalam tubuh. Ini memicu sel kekebalan lainnya untuk menghancurkan zat asing. Imunoglobulin G (IgG) adalah satu-satunya antibodi yang melintasi plasenta sampai janin selama kehamilan. Antibodi IgG adalah antibodi terkecil namun paling melimpah, yang menghasilkan $75-80 \%$ antibodi di tubuh. Mereka hadir dalam semua cairan tubuh dan mereka dianggap sebagai antibodi yang paling penting untuk melawan infeksi bakteri dan virus. Antibodi ini membantu melindungi janin dari berkembangnya infeksi di dalam rahim..

Segera setelah lahir, bayi sudah memiliki tingkat antibodi ibu yang tinggi dalam aliran darah. Bayi yang disusui terus mendapat antibodi melalui ASI. ASI mengandung kelima jenis antibodi, termasuk imunoglobulin $A(\lg A)$, imunoglobulin $D$ $(\lg D)$, imunoglobulin $\mathrm{E}$ ( $\lg \mathrm{E})$, $\lg \mathrm{G}$, dan imunoglobulin $\mathrm{M}(\lg M)$. Ini disebut kekebalan pasif karena sang ibu "melewati" antibodi-nya ke anaknya. Ini membantu mencegah bayi terkena penyakit dan infeksi.

Selama beberapa bulan berikutnya, antibodi yang ditularkan dari ibu ke bayi terus menurun. Bila bayi sehat berusia sekitar dua sampai tiga bulan, sistem kekebalan tubuh akan mulai menghasilkan antibodi sendiri. Selama masa ini, bayi akan mengalami titik rendah alami antibodi tubuh di aliran darah. Ini karena antibodi maternal telah menurun, dan anak-anak muda, yang membuat antibodi untuk pertama kalinya, menghasilkannya pada tingkat yang jauh lebih lambat daripada orang dewasa.

Bayi yang baru lahir mendapat dukungan sistem imunitas melalui air susu ibu (ASI) yang pertama kali keluar atau disebut kolostrum. Kolostrum mengandung immunoglobulin A $(\lg A)$ yang mampu melindungi tubuh bayi dari kuman. Caranya, dengan membentuk jaringan pelindung pada usus, hidung, dan tenggorokan.

Saat menyusui, bayi memperoleh antibodi dan faktor pelindung kuman lain dari tubuh ibunya. Kedua hal inilah yang akan memperkuat sistem imunitas. Hal tersebut akan membantu memerangi infeksi dan berbagai penyakit seperti diare, infeksi telinga dan pernapasan, serta meningitis. Bayi menyusui juga terlindung dari asma, obesitas, alergi, diabetes, serta sindrom kematian bayi mendadak atau sudden infant death syndrome (SIDS).

Sel limfosit T merupakan $80 \%$ dari sel limfosit yang terdapat dalam ASI. Sel limfosit $T$ dapat 
menghancurkan kapsul bakteri E. Coli dan mentransfer kekebalan selular dari ibu ke bayi yang disusuinya.

\section{KESIMPULAN}

Berdasarkan hasil penelitian pada bulan Mei sampai September 2018 terhadap 33 sampel darah pada Bayi yang mengkonsumsi ASI dan 44 sampel darah pada bayi yang mengkonsumsi susu formula adalah sebagai berikut :

1. Tidak ada perbedaan bermakna pada kesan jenis lekosit pada bayi yang mengkonsumsi asi dan susu formula kecuali pada Monosit ada perbedaan secara bermakna.

2. Ada satu orang yang meningkat netrofilnya pada bayi yang mengkonsumsi susu formula.

\section{SARAN}

Agar pada penelitian berikutnya dapat diperluas dan diperbanyak parameter pemeriksaan laboratorium pada bayi yang mengkonsumsi $\mathrm{ASI}$ dan yang mengkonsumsi susu formula

\section{UCAPAN TERIMA KASIH}

Kepada yang terhormat :

1. Direktur Poltekkes Kemenkes Makassar yang telah memberikan izin dalam penelitian ini.

2. Ketua Jurusan Analis Kesehatan Poltekkes Makassar yang telah memberikan support dan izin untuk melaksanakan penelitian.

3. Direktur Rumah Sakit se Kotamadya Makassar

4. Kepala Puskesmas se Kotamadya Makassar.

5. Kepada Seluruh teman sejawat yang telah berpartisipasi dan membantu dalam penelitian ini.

\section{DAFTAR PUSTAKA}

Anonim. 2017. Peran Imunitas Anak untuk Tumbuh Kembang yang Optimal. (http://www.alodokter.com/peran-imunitasanak-untuk-tum buh-kembang-yangoptimal). Diaskes pada tanggal 28 November 2017.

Dinas Kesehatan Pemerintah Kota Makassar. 2015. Profil Kesehatan Kota Makassar Tahun 2015. (dinkeskotamakassar.com). Diakses pada tanggal 28 November 2017.

Hanafi, Yusuf. 2012. Peningkatan Kecerdasan Anak Melalui Pemberian ASI dalam AlQuran. Malang: Jurnal Keilmuan Tafsir Hadis. (http://mutawatir. uinsby.ac.id/index.php/Mutawatir/article/vie $\mathrm{w} / 18)$. Diakses pada tanggal 28 November 2017.

Hidayat, A. A. (2012). Pengantar IImu Keperawatan Anak. Jakarta: Salemba Medika.

Hidayat, Anwar. 2017. Penjelasan Teknik Purposive Sampling. (https://www. statistikian.com/2017/06/penjelasan-teknikpurposive-sampling.html). Diakses pada tanggal 12 Desember 2017.

Marnoto, Budining Wirasatari. 2013. Pemberian Susu Formula pada Bayi Baru Lahir. (http://www.idai.or.id/artikel/klinik/asi/pemb erian-susu-formula-pada-bayi-baru-lahir). Diakses pada tanggal 28 November 2017.

Moedjito. 2015. Alasan Susu Formula Tidak Dianjurkan Untuk Bayi. (https://www.linkedin.com/pulse/alasansusu-formula-tidak-dianjurkan-untuk-bayidr-moedjito-hospital/). Diakses pada tanggal 28 November 2017.

Noor, Ronny. 2017. Dilema Meluasnya Penggunaan Susu Formula Bayi. (https://www.kompasiana.com/rrnoor/dilem a-meluasnya-penggunaan-susu-formulabayi 5979514af133445acc60a792). Diakses pada tanggal 28 November 2017. 